\title{
Ability grouping of gifted students: Effects on academic self-concept and boredom
}

\author{
Franzis Preckel ${ }^{1 *}$, Thomas Götz ${ }^{2,3}$ and Anne Frenzel ${ }^{4}$ \\ 'University of Trier, Germany \\ ${ }^{2}$ University of Konstanz, Germany \\ ${ }^{3}$ Thurgau University of Teacher Education, Kreuzlingen, Switzerland \\ ${ }^{4}$ LM University of Munich, Germany
}

\begin{abstract}
Background. Securing appropriate challenge or preventing boredom is one of the reasons frequently used to justify ability grouping of gifted students, which has been shown to have beneficial effects for achievement. On the other hand, critics stress psychosocial costs, such as detrimental effects on academic self concept (contrast or big fish little pond effect).
\end{abstract}

Aim. The effects of full time ability grouping in special classrooms for the gifted on students' academic self concept and their experience of boredom in mathematics classes were investigated.

Sample. The sample comprised 186 ninth grade students (106 male) from eight classes at one Austrian high school. Four of these classes were part of a gifted track beginning from school year 9 on $(N=93)$.

Method. Students were assessed repeatedly within the first half of the school year, three times via self report questionnaires and once by applying a standardized IQ test.

Results and conclusions. Students in gifted classes reported a decrease in maths academic self concept which was most pronounced early in the academic year. Interventions to counterbalance the negative effect of exposure to a high ability reference group should therefore be implemented when ability grouping begins. No evidence for the boredom hypothesis was found (higher levels of boredom among gifted students in regular classes). However, students clearly differed in the reasons they stated for experiencing boredom. Boredom attributions changed over time and supported the assumption that gifted classes provide more appropriate levels of challenge.

In this paper, we examine the effects of full-time ability grouping on students' academic self-evaluations and their experiences of boredom in class within special classes for the gifted. The effect of ability grouping on the academic self-concept of gifted students has

\footnotetext{
* Correspondence should be addressed to Professor Franzis Preckel, Department of Psychology, University of Trier, Giftedness Research and Education, 54286 Trier, Germany (e-mail: preckel@uni-trier.de).
} 
been investigated in several studies. Our study addresses a less frequently observed angle of this line of research by focusing on changes in academic self-concept over time (longitudinal approach). In addition, our study enhances research on the effects of ability grouping by taking into account the academic emotion of boredom within the classroom. To our knowledge, boredom has not yet been studied in the context of ability grouping of the gifted. This is surprising because preventing boredom and providing gifted students with appropriate academic challenge are frequently mentioned reasons to justify ability grouping gifted students into special classrooms (e.g., Plucker et al., 2004; Rogers, 2007).

\section{Ability grouping of the gifted in special classrooms}

Special classrooms for the gifted usually combine ability tracking with changes in curriculum aimed to increase the quality of education. There is ample empirical evidence that this form of grouping is beneficial for gifted students' achievement (e.g., Goldring, 1990; Hattie, 2002; Rogers, 1993, 2007; Shields, 2002) and some evidence for socioaffective benefits, like improved social relationships or more positive attitudes towards subject matters (for an overview, see Neihart, 2007). On the other hand, grouping gifted students has been criticized with respect to psychosocial costs, primarily citing its detrimental effects on academic self-concept. Marsh, Hau, and Craven (2004) state that due to a contrast effect, the big-fish-little-pond effect (BFLPE), many gifted students may suffer decreases in academic self-concept when they are grouped with other gifted students. This loss in academic self-concept is of high practical concern, as academic selfconcept has been found to have positive effects on subsequent academic achievement (Marsh et al., 2008; Valentine, DuBois, \& Cooper, 2004), academic choices (e.g., advanced coursework selection; Marsh, 1991), motivation variables (like academic interest; Marsh, Trautwein, Lüdtke, Köller, \& Baumert, 2005), educational and occupational aspirations (Marsh, 1991), and on academic emotions such as test anxiety (Goetz, Preckel, Zeidner, \& Schleyer, 2008) and enjoyment (Goetz, Frenzel, Hall, \& Pekrun, 2008). In the present study, when investigating the effects of being grouped with high-ability peers in special classes for the gifted, we contrast possible losses in academic self-concept with possible improvements with respect to boredom. Both academic self-concept and boredom are discussed as important predictors of academic learning and both constructs should be explicitly affected by ability grouping of gifted students, self-concept negatively, and boredom positively.

\section{The BFLPE on academic self-concept}

The BFLPE states that students of equal ability have lower academic self-concepts in classes or schools where the average ability or achievement level of classmates is $b i g h$, and higher academic self-concepts in classes or schools where the average ability or achievement level of classmates is low (Marsh, 1987). The BFLPE does not typically hold for non-academic facets of self-concept (e.g., social and physical self-concept). Marsh and Parker (1984) proposed a social frame-of-reference model to explain the BFLPE on academic self-concept. According to this model, self-perceptions in educational settings are largely shaped by the respective frame of reference. Students use the average level of academic achievement of their classmates or schoolmates as a frame of reference against which to evaluate their own academic standing. In addition, with increasing ability level of a reference group (school, class, etc.) teachers will compare individuals 
within classes with intellectually more able classmates. This negatively affects the feedback (e.g., marks, verbal feedback) students receive, i.e., most of them will be praised less than before entering the high track. Both processes, in turn, typically result in lower academic self-concepts (for overviews, see Köller, 2004; Marsh, 2005; Marsh et al., 2008).

The BFLPE has received large empirical support across diverse educational settings, populations, and cultures (e.g., Marsh \& Craven, 2002; Marsh \& Hau, 2003; Marsh et al., 2008). This holds true as well for gifted student populations when gifted students in regular classes are compared to gifted students in special classes for the gifted (e.g., Craven, Marsh, \& Print, 2000; Marsh, Chessor, Craven, \& Roche, 1995; Preckel \& Brüll, 2008; Shields, 2002; Zeidner \& Schleyer, 1998). However, some studies of gifted education programmes showed only short-term declines in academic self-concept, or even no declines at all (Dai \& Rinn, 2008). Following a line of reasoning formulated by Hattie (2002), Marsh et al. (2008) assume that other components of these programmes like different curricula, enrichment experiences, or highly trained teachers have a positive influence on students' academic self-concept, which confounds the negative effects of ability grouping. In addition, being grouped with other gifted students is likely to cause feelings of pride, thereby strengthening academic self-concept (assimilation or 'basking-in-reflected-glory' effect; Cialdini et al., 1976; Trautwein, Lüdtke, Marsh, \& Nagy, 2008). When controlling for the aforementioned factors, the BFLPE should be present. Some support for this assumption is provided by a study by Preckel, Zeidner, Goetz, and Schleyer (2008). Here, only gifted classes were investigated so that some of the factors that might have positive effects on academic self-concept could be controlled for. In support of the BFLPE, the average achievement levels of the classes had a substantial negative effect on academic self-concept when controlling for individual student ability. Thus, achievement level of the reference group also plays a crucial role in the formation of academic self-concepts within the gifted grouping.

The BFLPE seems to be a persistent, long-lasting phenomenon (Marsh, Trautwein, Lüdtke, Baumert, \& Köller, 2007). However, decreases in academic self-concept do not take place evenly over time but seem to appear most pronounced shortly after students change from a lower ability reference group to one of higher ability. In a longitudinal study of students in their first year of ability-grouped secondary school after the transition from non-ability-grouped primary school, Preckel and Brüll (2008) found decreases in academic self-concepts (general, maths, German) to be largest early in the academic year. In another longitudinal study, Huguet, Dumas, Monteil, and Genestoux (2001) also found the largest effects early in the first year at a new school. The change from a regular class to a more demanding class with higher average ability or achievement level of classmates changes the frame of reference. In addition, changing to a new class constitutes a transition period. In the new class, students have to adjust to new procedures, classmates, and - when being grouped in high-ability groups - to a more challenging curriculum and possibly a more competitive climate. Thus, in this transition period students need to cope with uncertainty regarding their academic standing (Wagner, 1999). Wagner (2001) provided evidence that students' certainty ratings of their academic self-concept decreased after entering secondary school. This uncertainty about one's ability in comparison to the reference group, combined with a possibly more competitive classroom situation, can be assumed to activate social comparisons (Festinger, 1954). Being grouped with other gifted students increases the likelihood for upward social comparisons which might, in turn, result in lower academic self-perceptions. 
Thus, the BFLPE should be most pronounced when new groups of students are formed and the social group and frame of reference are altered for students. Even though the BFLPE may also be observed within stable learning groups, as is the case when the ability level of the reference group accelerates at a greater pace than the individual ability level of a specific student (cf. Marsh, 1987, 1994), this effect should be rather small compared to the effects due to grouping. Therefore, we expect to find a BFLPE on academic self-concept when new and more homogeneous ability groups are formed for gifted students previously studying in regular, more heterogeneous classes, and we expect decreases in academic self-concept to be largest early in the new school year.

\section{Boredom in students}

Boredom is an emotion that has frequently been mentioned in the literature on gifted education. It is often reported that due to lack of challenge, gifted students face a higher level of boredom in school than their non-gifted peers (Plucker \& McIntire, 1996). Although, to our knowledge, boredom has not yet been studied in the context of ability grouping of the gifted. This is surprising, considering the fact that fostering gifted students by separating them into special programmes has frequently been justified with the provision of appropriate academic challenge leading to lower levels of boredom at school (e.g., Rogers, 2007).

Boredom is commonly seen as an affective state comprised of (weak) unpleasant feelings, lack of stimulation, and low physiological arousal (e.g., Mikulas \& Vodanovich, 1993). A central aspect of boredom is the dilatation of time, that is, people report that 'time stands still' when they experience boredom (Goetz \& Frenzel, 2006). In line with component theories of emotions (Kleinginna \& Kleinginna, 1981; Scherer, 2000), boredom can be described as an emotion consisting of affective (e.g., unpleasant feeling), cognitive (e.g., alerted perceptions of time), physiological (e.g., reduced arousal), expressive (e.g., vocal expression), and motivational components (e.g., motivation to change the activity). It is important to note that boredom implies more than the absence of positive emotions and interest. There are many subjective states that are not enjoyable but would not be qualified as boredom (e.g., anxiety, anger, shame). Similarly, given the components described, boredom clearly differs from lack of interest (for instance, lack of interest is affectively neutral).

Thus far, boredom has not received much attention in educational research (Pekrun, Goetz, Titz, \& Perry, 2002). Possible reasons might be that it is an inconspicuous, 'silent' emotion (unlike anger or anxiety) and is experienced by students as only faintly unpleasant (Goetz, Frenzel, \& Pekrun, 2007). This research gap is intriguing considering empirical findings relating student boredom to nicotine and alcohol consumption (Amos, Wiltshire, Haw, \& McNeill, 2006; Wiesner, Windle, \& Freeman, 2005), drug use (Anshel, 1991; Guinn, 1975), excessive gambling (Blaszcsynski, McConaghy, \& Frankova, 1990), juvenile delinquency (Newberry \& Duncan, 2001), depression and dissatisfaction with life (Farmer \& Sundberg, 1986), and stress and health problems when coupled with a need to maintain high levels of alertness (Thackray, 1981). Deviant behaviour (Wasson, 1981), truancy (Sommer, 1985), and drop-out (Bearden, Spencer, \& Moracco, 1989; Tidwell, 1988) of students have also been reported to be possible consequences of boredom. In the school context, theoretical approaches (e.g., Pekrun, 2006) and empirical results (e.g., Goetz, Pekrun, Hall, \& Haag, 2006) suggest that boredom negatively impacts motivation, the activation of cognitive resources, self-regulated learning, and achievement outcomes. 
Causes for boredom in school seem to be multifaceted (Robinson, 1975). In a recent study, Goetz, Frenzel, and Haag (2006) found the predominant cause of boredom in school to be instructional characteristics (e.g., too little diversity in instructional strategies). As an additional reason for boredom, students named aspects of the teacher personality (e.g., burnt-out teachers). Overall, students were able to differentiate quite clearly between causes of boredom located within the teachers' personality, specific aspects of instructional design, and causes that lie within the students themselves. Here, boredom was frequently explained by inappropriate levels of challenge. Even though boredom has traditionally been assumed to be caused by a lack of challenge (Csikszentmihalyi, 1975), interestingly, students expressed to be bored both due to underchallenge (e.g., already knowing the content well) and overchallenge (e.g., problems with understanding). Both under and overchallenge resulted in inappropriate levels of challenge and boredom, respectively. As most studies referring to challenge and boredom focus on gifted students who have to deal with environments that are tailored to the needs of average ability students (see below), boredom due to overchallenge has received less attention than boredom due to underchallenge (Acee et al., 2010; Csikszentmihalyi, 1990).

Research on boredom involving gifted students

In the educational literature, it is frequently assumed that gifted students experience boredom in school more frequently than their non-gifted peers (Plucker \& McIntire, 1996; Plucker et al., 2004). However, empirical support for this hypothesis is sparse and results are inconsistent. On the one hand, high cognitive abilities should generally coincide with success and, consequently, positive emotional experiences in class; the resulting overall favourable affective attitude towards school should be incompatible with negative emotional states including boredom. On the other hand, students with high cognitive abilities might perceive academic tasks as not very challenging, which could result in more frequent experiences of boredom (Goetz, Preckel, Pekrun, \& Hall, 2007). Thus, it is not clear whether these high-ability students experience higher or lower levels of boredom in the classroom.

In line with this, empirical results on high versus average ability students' experiences of boredom are inconsistent. For example, Larson and Richards (1991) found that during schoolwork, high-ability and high-achieving students (5th to 9th graders) experienced boredom more frequently than students of lower ability. On the other hand, Gjesme (1977), investigating 6th graders, found that high-ability students showed significantly lower levels of boredom at school than moderate- and low-ability pupils. Feldhusen and Kroll (1991), in turn, found no difference in self-reported boredom of 227 gifted and 227 non-gifted 4th through 6th graders. Also, studies investigating boredom and intelligence report all kinds of relationships (positive, negative, curvilinear, or no relationship; Farmer \& Sundberg, 1986) between the two constructs.

In part, these inconsistent results might be explained by sampling issues. While some studies investigated gifted students in the regular classrooms (Larson \& Richards, 1991), others assessed gifted students who received special fostering (e.g., Feldhusen \& Kroll, 1991). One study with 871 gifted students revealed higher levels of boredom for gifted students in regular classroom settings than in special courses for the gifted (Gallagher, Harradine, \& Coleman, 1997). While there are many possible causes for boredom in school (Goetz, Frenzel, et al., 2006; Robinson, 1975), lack of challenge is usually considered the main cause of boredom in gifted students (Kanevsky \& Keighly, 2003). 
Larson and Richards (1991) found that gifted students experienced more boredom than non-gifted students only during schoolwork. Outside school, however, gifted students were bored no more than non-gifted students, suggesting that boredom is not dispositional but rather relates to lack of stimulation and challenge in their classes. For the gifted, lack of appropriate challenge and boredom are discussed as the main predictors of academic underachievement (Freeman, 1993; Hoekman, McCormick, \& Barnett, 2005; Hoekman, McCormick, \& Gross, 1999; Rogers, 2002) or stress in class (Fimian, 1988).

Taken together, there is no clear theoretical assumption concerning the experience of boredom of gifted students as compared to non-gifted students. On the one hand, high cognitive abilities should coincide with positive emotional experiences due to success in class; consequently, boredom should be a less prominent emotion in these students. On the other hand, the lack of rewarding challenges for gifted students in regular classroom settings should result in higher levels of boredom. Therefore, the present study not only explored overall self-reported frequencies of boredom, but also inspected student boredom more in detail by integrating self-reported reasons for experiencing boredom: being underchallenged versus being overchallenged (referring to qualitative study on reasons for boredom of Goetz \& Frenzel (2006) and Goetz, Frenzel, et al. (2006)). To date, no quantitative study seems to have taken subjective reasons into account when exploring boredom. The present study is thus explorative and innovative in this respect. Nevertheless, two assumptions seem plausible here: first, gifted and non-gifted students are likely to differ in the degree to which they report boredom due to being over- versus underchallenged. Second, transitions to special classes for the gifted are likely to affect the degree to which gifted students report boredom due to being over- versus underchallenged.

\section{Research questions and hypotheses}

The present study addresses the effects of full-time ability grouping on students' academic self-evaluations and their experience of boredom in class. An important feature of the study is its longitudinal perspective. Half of the students changed from regular heterogeneous classes to special classes for the gifted. The other half remained in regular classes. The first two research hypotheses refer to academic self-concept, and the focus of the third hypothesis is on boredom in students. We expected the following:

(1) After transferring from regular to more selective classes with high achievement levels, students' academic self-concept should decrease due to the BFLPE; staying in a regular class should leave students' self-concepts unaffected.

(2) The decrease in academic self-concept will be most pronounced early in the year. Students seem to be most susceptible to the BFLPE during the initial transition to more selective classes because they have to adjust to a new frame of reference and need to cope with uncertainty regarding their academic standing (e.g., Burleson, 2005; Huguet et al., 2001).

(3) Boredom in the gifted was investigated in an explorative manner because previous research findings are inconsistent. Theoretical assumptions state that high cognitive ability could coincide with positive emotional experiences due to success in class, or with negative emotional experiences due to lack of challenge. Regarding subjective reasons for boredom, we assume that the gifted students will generally experience higher levels of boredom than regular students, due to being 
underchallenged; and that gifted students' boredom due to being underchallenged should decrease, whereas boredom due to being overchallenged should increase after the transition to special classes.

\section{Method \\ Participants}

We investigated ninth grade students in the top track of the Austrian school system. In the Austrian school system, after fourth grade, when students are about 10 years of age, and again after eighth grade when students are about 14 years of age, students are placed into different tracks according to their kind and level of achievement. 'Top track' does not refer to a track reserved for gifted students, since about $50 \%$ of the Austrian ninth grade students attend this kind of track (which leads to the Austrian Matura that qualifies students for university studies). The sample of this study consisted of 186 students (106 male/79 female; 1 unspecified). Students' mean age was 14.75 years (SD 0.84). They attended eight different classes at one high school. Within this particular school, there are special homogeneous classes for gifted students in addition to the regular classes from grade nine on. Four of the classes were part of such a gifted track within this school ( $N \quad 93 ; 38 \%$ female). All of the students in these gifted classes had attended regular classes at the same high school or other high schools up to grade eight. The other four classes were regular classes and class composition stayed unchanged between grade eight and nine ( $N \quad 93 ; 46 \%$ female). Students were selected for participation in gifted classes by multiple criteria: parent nominations, IQ, school marks, and teacher evaluations. Students in gifted classes showed significantly higher IQs than students in regular classes $(t$ 9.85, $d f$ 114.47, $p<.01$, effect size $d$ 1.63): the mean IQ (KFT $4 \quad 12+\mathrm{R}$; see Method section) for students in gifted classes was $M \quad 124.18$ (SD $12.12 ; N \quad 83$ ) and for students in regular classes $M \quad 98.93$ ( $S D \quad 18.20 ; N \quad 69$ ). In addition, students in gifted classes had significantly higher average marks in grade eight $(t \quad 9.17$, df $135.15, p<.01$, effect size $d$ 1.44). Students of both class types did not differ with respect to gender composition of classes $\left(\begin{array}{lll}Z & 1.04, p & .30\end{array}\right)$, but students in gifted classes were significantly younger (mean difference of 6 months; $t \quad 5.50, d f \quad 160.77, p<.01$ ).

\section{Design}

Data collection took place in three waves during the first half of grade nine: once within the first week of the new school year (t1), 10 weeks later (t2), and finally at the end of the school year ( 3 ; 15 weeks later than $t 2)$. Demographic and psychological data were gathered by a self-report instrument that was administered in groups at every wave of data collection during the regular lesson. Four months after the start of the new school year, the students' IQ was assessed by a standardized test, also administered to students in groups.

\section{Variables and measures}

Given that a number of psychosocial constructs, including academic self-concept (Bong, 2001) and emotions (Goetz, Frenzel, et al., 2007; Goetz, Pekrun, et al., 2006), have been shown to be rather domain-specific in nature, we focused on one academic domain in our study, namely, mathematics. Boredom has been shown to be a salient emotion in this domain (Goetz, Frenzel, \& Pekrun, 2007; Goetz, Preckel, et al., 2007). The following variables were assessed and analysed in the course of this study. 
Academic self-concept in mathematics

Academic self-concept in mathematics (e.g., 'Maths is one of my best subjects') was assessed with the German short version of the Self-Description Questionnaire (SDQ II-S) developed by Marsh (1990, 2007). Participants responded to five items on a 1 (strongly disagree) to 5 (strongly agree) point Likert scale. Reliabilities (Cronbach's alpha) for all three waves of data collection were $\alpha .74 / .89 / .87$ ( $N$ 158/151/142; after imputation of missing data (see below: handling of missing data), with $N$ 186: $\alpha \quad .75 / .90 / .87)$.

\section{Frequency of boredom}

We used a scale from the Achievement Emotions Questionnaire - Mathematics (Pekrun, Goetz, \& Frenzel, 2005) which has been shown to have high structural and convergent validity (e.g., relations with achievement; Goetz, Frenzel, \& Pekrun, 2007; Goetz, Frenzel, Pekrun, Hall, et al., 2007). The scale consists of six items (sample item: 'I am often bored in mathematics classes') with the response format of a Likert scale ranging from 1 (strongly disagree) to 5 (strongly agree). Reliabilities (Cronbach's alpha) for all three waves of data collection were $\alpha \quad .91 / .92 / .92$ (with $N$ 152/152/143; after imputation of missing data, with $N \quad 186: \alpha \quad .92 / .93 / .92)$.

\section{Reasons for boredom}

Two scales from the Konstanz Antecedents of Boredom Scales (Daschmann, Stupnisky, Nett, \& Goetz, 2009) were administered. These scales refer to the domain of mathematics and are based on existing theoretical approaches to the antecedents of boredom at school. They show both high structural and convergent validity (e.g., clear relations in the anticipated directions with aspects of instruction at school and conformity with assumed gender differences; Daschmann, Goetz, \& Stupnisky, 2009). Items were formulated as attributional statements, with a five-point Likert scale ranging from 1 (strongly disagree) to 5 (strongly agree) as response format. The scale Boredom due to being overchallenged consisted of four items (sample item: 'When I'm bored in mathematics classes, this is because the subject matter is too difficult for me'). The reliabilities (Cronbach's alpha) of this scale for the three waves of data collection were $\alpha \quad .88 / .88 / .91$ ( $N$ 156/151/142; after imputation of missing data, with $N$ 186: $\alpha \quad .87 / .89 / .92)$. The second scale, Boredom due to being underchallenged consisted of three items (sample item: 'When I'm bored in mathematics classes, this is because the subject matter is too easy') and showed reliabilities of $\alpha .86 / .85 / .84$ ( $N$ 156/153/143; after imputation of missing data, with $N \quad 186: \alpha \quad .87 / .85 / .84$ ) for waves $1 / 2 / 3$.

Academic achievement in mathematics and German Students self-reported their marks in mathematics and German from their final record in grade eight (first wave) and their first term record in grade nine (third wave). Recent research supports that self-reported school marks can be assumed to be valid, since they do not seem to be subject to systematic bias (Dickhäuser \& Plenter, 2005). In addition, the self-reported marks in the present study did not reflect marks from single tests but instead cumulative achievements of an entire school year, which can be assumed to have higher validity than single marks. Marks ranged from 1 (very good) to 5 (insufficient), with higher numbers representing poorer achievement. To allow for 
coefficients involving these achievement measures to be interpreted in a more intuitive manner, students' marks were inverted so that higher numbers indicate higher achievement levels.

\section{Intelligence}

Intelligence (verbal, numerical, and figural reasoning as well as composite IQ) was assessed with the KFT $4 \quad 12+\mathrm{R}$ (Kognitiver Fähigkeitstest/Cognitive abilities test; Heller \& Perleth, 2000; $M \quad 100 ; S D \quad 15)$. The KFT $4 \quad 12+\mathrm{R}$ is a German adaptation of the Cognitive Abilities Test developed by Thorndike and Hagen (1971), last revised in 1996. In Germany, the KFT $4 \quad 12+\mathrm{R}$ is one of the most frequently used intelligence tests and is also used in research on giftedness and education. The test was presented in paper-and-pencil format. Correlations of test results with academic achievement were as follows: maths mark and numerical reasoning $r \quad .60(N \quad 145)$; German mark and $\begin{array}{lll}\text { verbal reasoning } r & .45\end{array}\left(\begin{array}{ll}N & 140\end{array}\right)$; IQ and average mark $r \quad .62\left(\begin{array}{ll}N & 144\end{array}\right)$. Sample alpha was .93 for IQ (composite score), .84 for verbal reasoning, .91 for numerical reasoning, and .90 for non-verbal reasoning $(N \quad 153)$.

\section{Data analysis}

Handling of missing data

Because of the longitudinal design of the present study, the number of cases with missing data for single items of the academic self-concept and boredom scales was substantial and varied between 14.0 and $23.1 \%$. As the $p$-value for Little's MCAR (missing completely at random) test was not significant, the data can be assumed to be missing completely at random $\left(\chi^{2} \quad 1,629.96, d f \quad 1,599, p \quad .29\right)$. Thus, results could be reported with listwise deletion of cases. However, because the number of cases with missing data clearly exceeded 5\% for several items, we decided to impute missing data by using maximum-likelihood estimation (EM algorithm in the SPSS missing values option). Because this procedure might result in biased estimations of standard errors and thereby cause significance tests to be too liberal, results for inferential statistics are compared with the results when using listwise deletion of cases.

\section{Analysis procedures}

First, descriptive statistics for self-concept and boredom variables were inspected separately for ability group and wave of measurement, and intercorrelations of scales are reported. Hypothesis 1 (decrease in maths academic self-concept) was tested by a repeated measures analysis of variance (within-subject factor: time, between-subject factor: type of class). Hypothesis 2, which states that the decrease in maths academic self-concept is most pronounced at the beginning of the school year, was investigated by comparing effect sizes $d$ of self-concept changes between two consecutive waves of measurement, respectively. Research question 3 regards the explorative analysis of differences between ability groups in frequency of boredom as well as the expectation of a decrease in boredom due to being underchallenged and an increase in boredom due to being overchallenged after ability grouping. Group differences in boredom frequency were tested by repeated measures analysis of variance (within-subject factor: time, between-subject factor: ability group). Group differences for both reasons for boredom 
were tested by a MANOVA with repeated measures (within-subject factor: time, between-subject factor: ability group).

\section{Results}

Descriptive statistics are given in Table 1. Table 2 shows the intercorrelations of all measures over all waves of measurement. Academic self-concept in mathematics showed good retest reliability. Retest reliabilities of frequency of boredom and reasons for boredom were noticeably lower, but still highly significant. Academic self-concept was negatively related to frequency of boredom (with only one exception, ASC 1 and BO FR1: small to midsize correlations) and boredom due to being overchallenged (midsize to large correlations) and positively related to boredom due to being underchallenged (midsize correlations). That is, students who evaluated their abilities in mathematics to be higher experienced less boredom in class and explained feelings of boredom by being underchallenged rather than by being overchallenged, as compared to students who rated their abilities lower. Frequency of boredom in mathematics was positively related to boredom due to being overchallenged (small to midsize correlations) and weakly, but also positively related to boredom due to being underchallenged. As could be expected, both reasons for boredom were negatively related with each other (midsize correlations).

Hypothesis 1, which states that academic self-concept of the gifted will decrease due to the BFLPE when attending more selective classes, could be confirmed. We found

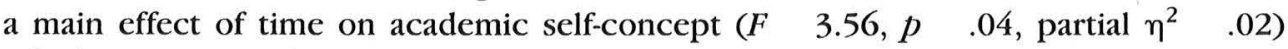
which was qualified by a highly significant interaction between time and ability group ( $F \quad 7.53, p<.01$, partial $\eta^{2} \quad .04$ ). ${ }^{1}$ This implies a decrease in academic self-concept for the gifted students; for the regular students, no comparable change could be shown (see Figure 1). Hypothesis 2, which expects self-concept changes to be most pronounced early during the school year, could also be confirmed. Here, only gifted students were taken into account since students studying in regular classes did not show comparable changes in academic self-concept. The effect size for this change between the first and second waves of measurement was $d \quad 0.31$ whereas the effect size for self-concept change between the second and third waves of measurement was $d \quad 0.03$.

Relations between student ability, ability grouping, and boredom measures were investigated in an explorative manner since high cognitive ability could coincide with both positive emotional experiences due to success in class and negative experiences due to lack of challenge. Results of the ANOVA with repeated measures for frequency of boredom (within-subject factor: time, between-subject factor: ability group) yielded no differences in frequency of boredom between gifted and regular students (ability group: F $\quad 0.23, p \quad .63$, partial $\left.\eta^{2} \quad .00\right)$. This finding held both when comparing gifted students' ratings of their experiences in regular classroom settings with the ratings of regular students studying in regular classes (wave 1) and when comparing gifted students' ratings of their experiences in special classes for the gifted with the ratings of regular students in regular classes (waves 2 and 3; see Figure 2). For both ability groups,

\footnotetext{
' Reported values refer to statistical results obtained with Greenhouse Geisser corrected degrees of freedom. Results were comparable when using data with listwise deletion of cases (time: $\mathrm{F}=11.54, \mathrm{p}<.01$, partial $\eta^{2}=.10$; time $\times$ ability group: $\mathrm{F}=13.28, \mathrm{p}<.01$, partial $\left.\eta^{2}=.11 ; \mathrm{N}=110\right)$.
} 
Table I. Descr pt ve stat st cs for se f-concept and boredom measures by wave and ab ty group ( $\mathrm{g}$ fted and regu ar $\mathrm{c}$ asses; $N=186$ )

\begin{tabular}{|c|c|c|c|c|c|c|c|c|c|}
\hline & \multicolumn{3}{|c|}{ Wave I } & \multicolumn{3}{|c|}{ Wave 2} & \multicolumn{3}{|c|}{ Wave 3} \\
\hline & A & G fted & Regu ar & A & G fted & Regu ar & A & G fted & Regu ar \\
\hline Maths ASC, $M(S D)$ & $3.38(0.97)$ & $3.81(0.77)$ & $2.95(0.96)$ & $3.26(1.07)$ & $3.53(1.00)$ & $2.99(1.08)$ & $3.26(1.11)$ & $3.50(1.05)$ & $3.01(1.11)$ \\
\hline Frequency of boredom, $M(S D)$ & $2.23(0.95)$ & $2.24(1.04)$ & $2.23(0.86)$ & $2.33(1.07)$ & $2.25(1.09)$ & $2.41(1.06)$ & $2.37(1.00)$ & $2.36(1.07)$ & $2.39(0.92)$ \\
\hline $\begin{array}{l}\text { Boredom due to be } n g \\
\text { overcha enged, } M(S D)\end{array}$ & $2.11(0.99)$ & $1.72(0.79)$ & $2.50(1.02)$ & $2.48(1.20)$ & $2.19(1.14)$ & $2.77(1.20)$ & $2.51(1.20)$ & $2.27(1.12)$ & $2.75(1.24)$ \\
\hline $\begin{array}{l}\text { Boredom due to be ng } \\
\text { undercha enged, } M(S D)\end{array}$ & $2.99(1.15)$ & $3.46(0.98)$ & $2.51(1.12)$ & $2.38(1.07)$ & $2.49(1.13)$ & $2.28(1.00)$ & $2.28(1.02)$ & $2.31(1.04)$ & $2.25(1.01)$ \\
\hline
\end{tabular}


Table 2. Corre at ons of measures of academ c se f-concept and boredom $(N=186)$

\begin{tabular}{|c|c|c|c|c|c|c|c|c|c|c|c|}
\hline & ASC2 & ASC3 & BO_FRI & BO_FR2 & BO_FR3 & BO_OCl & BO_OC2 & BO_OC3 & BO_UCI & BO_UC2 & BO_UC3 \\
\hline $\mathrm{ASCl}$ & $.72 * *$ & $.70^{* * * ⿰ ㇇ ⿰ 亅 ⿱ 丿 丶 丶 ~}$ & -.08 & $-.24 *$ **⿰㇇⿰亅⿱丿丶丶 & $-.18^{*}$ & $-.69 * *$ & $-.55 * *$ & $-.44^{* *}$ & $.63 * *$ & $.38^{* * *}$ & $.40 * *$ \\
\hline ASC2 & & $.87^{\text {*ak }}$ & 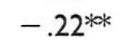 & $-.42^{* k}$ & -.30 **o & $-.63 * *$ & $-.75^{* * *}$ & $-.70^{* * *}$ & $.50 \% *$ & $.46 *$ & $.43 * *$ \\
\hline ASC3 & & & $-.21 * *$ & $-.36 * *$ & $-.34 * *$ & $-.59 * *$ & $-.69 * *$ & $-.70 * *$ & $.39 * *$ & $.41^{* * *}$ & $.46 * \%$ \\
\hline BO_FRI & & & & $.61^{* * *}$ & $.44^{* * *}$ & $.17 *$ & $.18 *$ & $.19 * *$ & $.18^{*}$ & $.26 * * k$ & $.20 \% *$ \\
\hline BO_FR2 & & & & & $.66 * *$ & $.24 * *$ & $.43 * *$ & $.44^{* * *}$ & -.02 & $.18^{*}$ & .04 \\
\hline BO_FR3 & & & & & & .14 & $.36 * *$ & $.42^{* * *}$ & $.15 *$ & .14 & $.22^{* * \%}$ \\
\hline BO_OCl & & & & & & & $.61^{* * *}$ & $.55^{* * *}$ & $-.55 * *$ & $-.33 * *$ & $-.26 * *$ \\
\hline BO_OC2 & & & & & & & & $.79 * *$ & $-.39 * *$ & $-.30 * *$ & $-.26^{\text {* }}$ \\
\hline BO_OC3 & & & & & & & & & $-.30 * k$ & $-.28 * *$ & $-.34^{* k}$ \\
\hline BO_UCl & & & & & & & & & & $.54 * *$ & $.46 * 2$ \\
\hline BO_UC2 & & & & & & & & & & & $.56^{* * *}$ \\
\hline
\end{tabular}

Notes. Numbers I-3 nd cate the respect ve wave of measurement; ASC, academ c se f-concept; BO_FR, frequency of boredom; BO_OC, boredom due to be ng overcha enged; BO_UC, boredom due to be ng undercha enged; $* p<.05 ; * * p<.01$. 


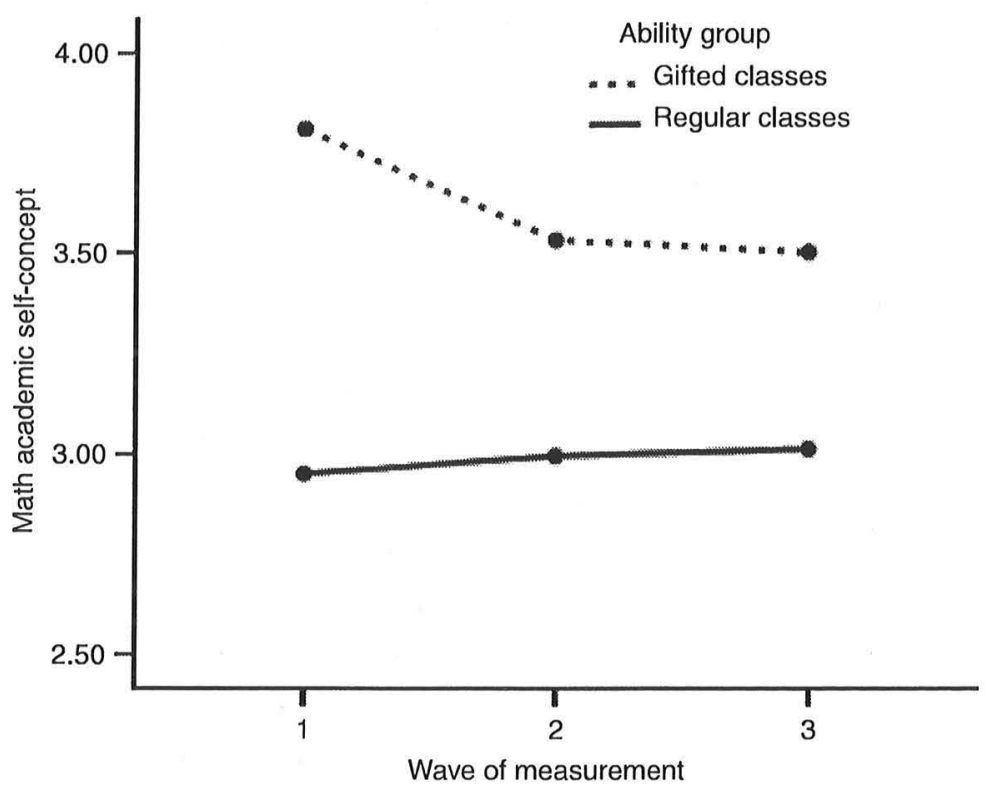

Figure I. Math academic self concept for ability groups over the three waves of measurement.

frequency of boredom did not changeover time (time: $F \quad 2.19, p \quad .12$, partial $\eta^{2} \quad .01 ;$ time $\times$ ability group: $F \quad 0.80, p \quad .44$, partial $\eta^{2}$ $.00) .^{2}$

Finally, we had assumed that the gifted students would experience more challenge in special classes as compared to regular classes and thus report being underchallenged as a reason for boredom less frequently, and being overchallenged as a reason for boredom more frequently after the transition. Indeed, we found evidence for changes in the expected directions for the reasons for boredom (see Table 3 and Figure 2).

Results of the MANOVA with dependent variables reasons for boredom (being underchallenged or overchallenged), and independent variables time (within-subject factor) and ability group (between-subject factor: gifted vs. regular classes) were as follows: reasons for boredom changed over time (significant main effect of time). However, there were no main effects for giftedness or for reason for boredom: students overall were not systematically more bored due to being over-or underchallenged, and independent of time and reason for boredom - gifted students' ratings did not differ from the ratings of regular students. All two-way interactions were significant. ${ }^{3}$ However, because the three-way interaction was significant as well, the two-way interactions were interpreted in the context of the three-way interaction. The significant three-way interaction (time $\times$ reason for boredom $\times$ ability group) revealed a specific developmental pattern for each of the two reasons for boredom among the two different groups of students: among regular students, only minor changes in boredom due to being over- or underchallenged occurred, whereas among gifted students, considerable developmental changes - especially for boredom due to being underchallenged - took

\footnotetext{
${ }^{2}$ Reported values refer to statistical results obtained with Greenhouse Geisser corrected degrees of freedom. Results were comparable when using data with listwise deletion of cases (time: $\mathrm{F}=0.22, \mathrm{P}=.81$, partial $\eta^{2}=.00$; ability group: $\mathrm{F}=0.06, \mathrm{p}=.63$, partial $\eta^{2}=.00$; time $\times$ ability group: $\mathrm{F}=0.86, \mathrm{p}=.43$, partial $\eta^{2}=.01 ; \mathrm{N}=113$ ).

${ }^{3}$ The two-way interaction of time $\times$ ability group, however, only gained significance with imputed data and should therefore be treated with caution. Otherwise, results between listwise deletion of cases and imputed data were comparable.
} 

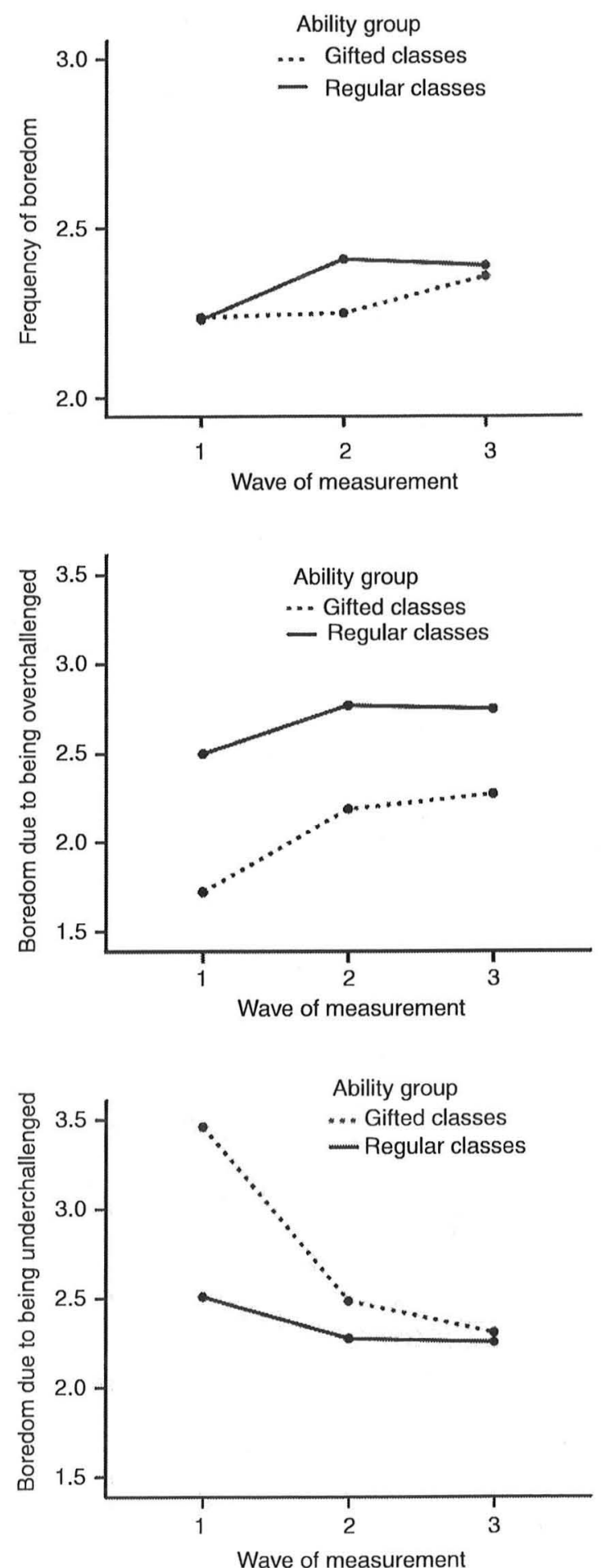

Figure 2. Boredom frequency and reasons for boredom for ability groups over the three waves of measurement. 
Table 3. Results of the MANOVA with repeated measures to test the effects of time over the three waves of measurement and ability groups (gifted and regular classes) on reasons for boredom $(N=186)$

\begin{tabular}{lrrrr}
\hline Source & $F$ & $d f$ & Partial $\eta^{2}$ & $p$ \\
\hline Time & 5.65 & 2 & .06 & $<.01$ \\
Reason for boredom & 2.67 & 1 & .01 & .10 \\
Ability group & 2.06 & 1 & .01 & .15 \\
Time $\times$ reason for boredom & 49.58 & 2 & .35 & $<.001$ \\
Time $\times$ ability group & 5.95 & 2 & .06 & $<.01$ \\
Reason for boredom $\times$ ability group & 20.43 & 1 & .10 & $<.001$ \\
Time $\times$ reason for boredom $\times$ ability group & 13.21 & 2 & .13 & $<.001$ \\
\hline
\end{tabular}

place. Overall, gifted students reported more boredom due to being underchallenged, whereas non-gifted students reported more boredom due to being overchallenged. For the gifted, boredom due to being underchallenged was mentioned more frequently at the beginning of the school year and then less and less, whereas boredom due to being overchallenged showed the opposite developmental trajectory (see Figure 1).

Separate follow-up ANOVAs for the different reasons for boredom between groups of students confirmed that changes in both reasons for boredom were non-significant for regular students, but both the increase in boredom due to being overchallenged and the decrease due to being underchallenged yielded significance for the gifted students.

\section{Discussion}

In the present study, the effects of full-time ability grouping in special classrooms for the gifted on students' academic self-evaluations and their experience of boredom in mathematics classes were investigated. One strength of the study is that students were assessed three times after a transition from regular mixed-ability classrooms to the first year in more homogeneous high-ability classrooms (special classes for the gifted). Thus, we could investigate development over time. In addition, gifted students' developmental trends of self-concept and boredom over time could be compared with those of students who remained in regular classes during the same developmental period.

Departing from the social frame-of-reference model proposed by Marsh and Parker (1984) and findings on the BFLPE, we expected gifted students to report a decrease in academic self-concept when attending more selective classes. Moreover, we expected that this decrease would be most pronounced early in the year because during this time students need to cope with increased uncertainty regarding their academic standing in the new class. A further aim of this study was to investigate boredom. In addition to exploring the frequency of boredom experienced in class, subjective causes for boredom (boredom due to being overchallenged vs. due to being underchallenged) were investigated. Our analyses regarding frequency of boredom among gifted versus regular students were exploratory, because both higher and lower frequencies of boredom among gifted students are theoretically conceivable and empirical evidence regarding this question is mixed. With respect to reasons for boredom, we expected the gifted to experience more challenge in special classes as compared to regular classes and thus to report decreasing levels of boredom due to being underchallenged, and increasing levels of boredom due to being overchallenged over time.

Before discussing our findings, we would like to point to some limitations of our study. Of note, we only assessed self-concept and boredom in mathematics. For other subjects 
findings might differ. Most measures employed in our study (except IQ-tests) were selfreports. The self-reports might have been influenced by factors like social desirability and stereotyping. Furthermore, generalizability of the present findings is limited; it should be taken into account that the sample consisted of ninth grade Austrian students only. Further studies are needed to investigate whether our findings can be replicated in other cultures, and in students of different ages. Last, but not least, the sample size of the present study did not allow the cluster structure of the data to be taken into account (students were grouped in their classrooms). Thus, we could not carry out an optimal test of the BFLPE by applying HLM (hierarchical linear modeling) methodology and looking for positive correlations between achievement and self-concept on an individual level and, when controlling for this effect, negative correlations between group-level achievement and self-concept.

\section{Changes in academic self-concept over time}

While academic self-concept in mathematics remained unchanged for regular students in regular classes, gifted students who had changed from regular classes to more homogeneous high-ability classrooms (special classes for the gifted) reported significant decreases in academic self-concept. This data pattern fully conforms to expectations based on the BFLPE on academic' self-concept. Alternatively, one could argue that during the time before the first wave of measurement of the present study, the gifted students had received a boost to their academic self-concept by being accepted to a gifted track, resulting in an assimilation- or basking-in-reflected-glory-effect (Cialdini et al., 1976; Trautwein et al., 2008). Following their ongoing engagement with their new class, this gain might have been only of short duration due to contrast- or habituation-effects. In the present study, there is no data on students' academic self-concept from the time before they knew that they were accepted to the gifted track. Thus, this alternative explanation could not be tested. However, as pointed out in the introductory section, many studies document a BFLPE on academic self-concept for gifted students after ability grouping. Of note, recent longitudinal research on the development of academic self-concept of fifthgrade students in gifted classes documents negative contrast effects of group average ability even after controlling for positive assimilation effects of belonging to the gifted track (Brüll, 2009). In addition, it is not very likely that mean group differences between students from gifted and regular classes in academic self-concept at the first wave of measurement can mainly be traced back to positive assimilation effects. Gifted students are typically found to have higher academic self-perceptions (Hoge \& Renzulli, 1993; McCoach \& Siegle, 2003; Pyryt \& Mendaglio, 1994) - even after ability grouping (McCoach \& Siegle, 2003; Zeidner \& Schleyer, 1998). Also, in the present study, after the decrease between the first two waves of measurement gifted students' academic selfconcept was still higher than regular students' academic self-concept. Some authors therefore do not consider the impact of ability grouping on academic self-concepts of the gifted to be negative or alarming ' $(.$.$) because self-concept frequently remains at$ a reasonable level (... )' (Plucker et al., 2004, p. 268). We believe it is an open question as to what constitutes 'reasonable levels of self-concept' in this context. As described in the introductory section, academic self-concept is a powerful predictor for a variety of variables related to achievement and learning. In addition, the BFLPE seems to be a longlasting phenomenon. Comparing the academic self-concept of gifted students after ability grouping to the academic self-concept of non-gifted students can hardly be taken as an argument in support of ability grouping. This is because comparing the gifted to the 
non-gifted disguises the loss in academic self-concept experienced by the gifted, which can be assumed to have negative effects on achievement and learning.

In a cost-benefit analysis of ability grouping, Plucker et al. (2004) weighed losses in academic self-concept against appropriate challenge or the prevention of boredom, respectively, and the related benefits for student motivation and interest. Empirical evidence of the achievement-related benefits of grouping the gifted is strong (Rogers, 2007). Also, there is evidence for some socio-affective benefits (Neihart, 2007). Nonetheless, one should not ignore possible negative consequences of a decrease in academic self-concept due to the BFLPE which might be masked by the positive effects of ability grouping. There is still a lack of longitudinal research, which may be able to disentangle these effects and show long-range consequences of ability grouping for the gifted, as well as possible starting-points for interventions.

One such starting-point might be deduced from our finding that decreases in academic self-concept of gifted students were largest early in the school year. Thus, our data is in support of studies showing that most decreases in self-concept occur shortly after placement in the new reference group (e.g., Burleson, 2005; Huguet et al., 2001; Wagner, 2001). We found that decreases in academic self-concepts were largest during the first 10 weeks in the new class, and that there were no more decreases after this point in time. Therefore, interventions to counterbalance the negative effects of the BFLPE on academic self-concept might be most beneficial early in or right at the beginning of the new school year.

Notably, none of the students in our sample had received any teacher-assigned school marks during the first 10 weeks in the new class. Thus, our results indicate that decreases in academic self-concept as a consequence of changing to a higher-ability reference group also take place without teacher-assigned school marks. Results of other studies also reveal that decreases in academic self-concept due to the BFLPE cannot be reduced to being a consequence of getting lower marks in higher ability classes. Negative effects of group average achievement could still be demonstrated after controlling for teacher assigned school marks (Brüll, 2009; Lüdtke, Köller, Artelt, Stanat, \& Baumert, 2002; Marsh, 1987; Trautwein, Lüdtke, Marsh, Köller, \& Baumert, 2006). Refraining from assigning marks to prevent decreases in academic self-concept due to the BFLPE therefore does not seem to be sufficient. One approach which might be more promising is to have teachers use individual frames of reference when providing students with achievement-related feedback (instead of a social or achievement-criteriarelated frame of reference). An individual frame of reference might counterbalance the negative effect of an increased level of class achievement on individual academic selfconcept by reducing the amount of students' comparisons of individual achievement outcomes with those of other students in class. Individual frames of reference employed by teachers have been found to have positive effects on students' academic selfperceptions, along with a variety of cognitive, motivational, and affective variables (Köller, 2004). The results of the present study lead us to assume that such an intervention should be implemented early in the new school year.

\section{Boredom}

As stated above, Plucker et al. (2004) weighed losses in academic self-concept as a consequence of ability grouping against appropriate challenge or the prevention of boredom, respectively. To our knowledge, however, empirical evidence for the reduction of boredom through ability grouping is missing. In our study, ability grouping had no 
consequences for the overall frequency of boredom reported by the gifted. Also, we found no evidence for the boredom hypothesis, that is, higher levels of boredom among gifted students in regular classes. It should be taken into account that students in our sample were enrolled in the most demanding regular school track in Austria. Thus, boredom of gifted students might be a more frequent problem in less demanding school types. Nevertheless, previous research findings on the boredom hypothesis are inconsistent; and theoretical assumptions state that high cognitive ability could coincide with positive emotional experiences due to success in class on the one hand, and lack of challenge on the other hand. Further research is needed in which both mechanisms can be separated.

Our study provides more detailed insights into the phenomenon of boredom among gifted and non-gifted students by incorporating subjective reasons for being bored: due to being over- or due to being underchallenged. While we found no group differences in the overall frequency of boredom, gifted and non-gifted students clearly differed in the reasons they stated for experiencing boredom. Overall, gifted students reported boredom due to being underchallenged more frequently, whereas non-gifted students reported boredom due to being overchallenged more frequently. In addition, these boredom attributions changed as a consequence of ability grouping. While we found no changes in boredom attributions for non-gifted students over time, for the gifted, boredom due to being underchallenged decreased, whereas boredom due to being overchallenged increased.

Up to now, being overchallenged as a reason for boredom has received less attention in research literature than being underchallenged (Acee et al., 2010; Csikszentmihalyi, 1990). However, in our study, both reasons for boredom were significantly correlated to frequency of boredom, and correlations between being overchallenged with frequency of boredom were even stronger than correlations of being underchallenged as a reason. The finding that gifted students' boredom due to being underchallenged decreased after their transition to the special gifted class can be interpreted as a positive argument for ability grouping, since challenge is one important aspect of (gifted) students perceptions of classroom quality (Gentry \& Springer, 2002). Grouping the gifted has negative (self-concept decreases) as well as positive (greater challenge) consequences. Further research is needed to disentangle these effects, and the knowledge gained could be used in gifted education in order to strengthen the positive effects and counterbalance the negative effects of ability grouping.

\section{References}

Acee, T. W., Kim, H., Kim, H. J., Kim, J. I., Chu, H. R., Kim, M., ... Wicker, F. W. (2010). Academic boredom in under and over challenging situations. Contemporary Educational Psychology, 35(1), 17 27. doi:10.1016/j.cedpsych.2009.08.002

Amos, A., Wiltshire, S., Haw, S., \& McNeill, A. (2006). Ambivalence and uncertainty: Experiences of and attitudes toward addiction and smoking cessation in the mid to late teens. Health Education Research, 21, 181191.

Anshel, M. H. (1991). A survey of elite athletes on the perceived causes of using banned drugs in sport. Journal of Sport Behavior, 14, 283310.

Bearden, L., Spencer, W., \& Moracco, J. (1989). A study of high school dropouts. School Counselor, 37, 113120.

Blaszcsynski, A., McConaghy, N., \& Frankova, A. (1990). Boredom proneness in psychopatho logical gambling. Psychological Reports, 67, 3542. 
Bong, M. (2001). Between and within domain relations of academic motivation among middle and high school students: Self efficacy, task value and achievement goals. Journal of Educational Psychology, 93, 2334.

Brüll, M. (2009). Akademisches Selbstkonzept und Bezugsgruppenwechsel: Eine Untersuchung von Kontrast und Assimilationseffekten sowie von Einflussfaktoren auf Veränderungen im akademischen Selbstkonzept bei überdurchschnittlich begabten Kindern nach einem Bezugsgruppenwechsel [Academic self concept and change of reference group: Studying contrast and assimilation effects and factors that influence self concept changes after changing the reference group]. Unpublished dissertation. University of Trier, Trier.

Burleson, K. A. P. (2005). Social comparisons at gifted schools for the arts: Qualifications for the big fish little pond effect. Dissertation Abstracts International: Section B: The Sciences and Engineering, 66, 1195.

Cialdini, R. B., Borden, R. J., Thorne, A., Walker, M. R., Freeman, S., \& Sloan, L. R. (1976). Basking in reflected glory: Three (football) field studies. Journal of Personality and Social Psychology 34,366375 .

Craven, R. G., Marsh, H. W., \& Print, M. (2000). Gifted, streamed, and mixed ability programs for gifted students: Impact on self concept, motivation, and achievement. Australian Journal of Education, 44, 5175.

Csikszentmihalyi, M. (1975). Beyond boredom and anxiety. San Francisco, CA: Jossey Bass.

Csikszentmihalyi, M. (1990). Flow: The psychology of optimal experience. New York: Harper and Row.

Dai, Y. D., \& Rinn, A. N. (2008). The big fish little pond effect: What do we know and where do we go from here? Educational Psychology Review, 20, 283317.

Daschmann, E. C., Goetz, T., \& Stupnisky, R. H. (2009). Causes of boredom at school. Validation of the Konstanz Antecedents to Boredom Scales. Manuscript submitted for publication.

Daschmann, E. C., Stupnisky, R., Nett, U. E., \& Goetz, T. (2009, April). Exploring the causes of boredom at school. Development and validation of the Konstanz Antecedents to Boredom Scales. Paper presented at the American Educational Research Association Annual Meeting, San Diego, DC.

Dickhäuser, O., \& Plenter, I. (2005). 'Letztes Halbjahr stand ich zwei'. Zur Akkuratheit selbst berichteter Noten ['Last term I had a B'. On the accuracy of self reported school grades] Zeitschrift für Pädagogische Psychologie, 19, 219224.

Farmer, R., \& Sundberg, N. D. (1986). Boredom proneness the development and correlates of a new scale. Journal of Personality Assessment, 50, 417.

Feldhusen, J. F., \& Kroll, M. D. (1991). Boredom or challenge for the academically talented in school. Gifted Education International, 7, 8081.

Festinger, L. (1954). A theory of social comparison processes. Human Relations, 7, 117140.

Fimian, M. J. (1988). Predictions of classroom stress and burnout experienced by gifted and talented students. Psychology in the Schools, 25, 392405.

Freeman, J. (1993). Boredom, high ability, and achievement. In V. P. Varma (Ed.), How and why children fail (pp. 29 40). London: Jessica Kingsley Publishers.

Gallagher, J., Harradine, C. C., \& Coleman, M. R. (1997). Challenge or boredom? Gifted students' views on their schooling. Roeper Review, 19, 132136.

Gentry, M., \& Springer, P. M. (2002). Secondary student perceptions of their class activities regarding meaningfulness, challenge, choice, and appeal: An initial validation study. Journal of Secondary Gifted Education, 13, 192204.

Gjesme, T. (1977). General satisfaction and boredom at school as a function of the pupils personality characteristics. Scandinavian Journal of Educational Research, 21, 113146.

Goetz, T., \& Frenzel, A. C. (2006). Phänomenologie schulischer Langeweile [Phenomenology of boredom at school]. Zeitschrift für Entwicklungspsychologie und Pädagogische Psychologie, $38,149153$.

Goetz, T., Frenzel, A. C., \& Haag, L. (2006). Ursachen von Langweile im Unterricht [Causes of boredom at school]. Empirische Pädagogik, 20, 113134. 
Goetz, T., Frenzel, A. C., Hall, N. C., \& Pekrun, R. (2008). Antecedents of academic emotions: Testing the internal/external frame of reference model for academic enjoyment. Contemporary Educational Psychology, 33, 933.

Goetz, T., Frenzel, A. C., \& Pekrun, R. (2007). Regulation von Langeweile im Unterricht: Was Schülerinnen und Schüler bei der 'Windstille der Seele' (nicht) tun [Regulation of boredom in class. What students (do not) do when experiencing the 'windless calm of the soul']. Unterrichtswissenschaft, 35, 312333.

Goetz, T., Frenzel, A. C., Pekrun, R., Hall, N. C., \& Lüdtke, O. (2007). Between and within domain relations of students' academic emotions. Journal of Educational Psychology, 99, 715733.

Goetz, T., Pekrun, R., Hall, N. C., \& Haag, L. (2006). Academic emotions from a social cognitive perspective: Antecedents and domain specificity of students' affect in the context of latin instruction. British Journal of Educational Psychology, 76, 289 308. doi:10.1348/ $000709905 \times 42860$

Goetz, T., Preckel, F., Pekrun, R., \& Hall, N. (2007). Emotional experiences during test taking: Does cognitive ability make a difference? Learning and Individual Differences, 17, 316.

Goetz, T., Preckel, F., Zeidner, M., \& Schleyer, E. J. (2008). Anxiety of big fish swimming in big ponds: A multilevel analysis of test anxiety and achievement in special gifted classes. Anxiety, Stress, and Coping, 21, 185198.

Goldring, E. B. (1990). Assessing the status of information on classroom organisational frameworks for gifted students. Journal of Educational Research, 83, 313326.

Guinn, R. (1975). Characteristics of drug use among Mexican American students. Journal of Drug Education, 5, 235241.

Hattic, J. C. (2002). Classroom composition and peer effects. International Journal of Educational Research, 37, 449481.

Heller, K. A., \& Perleth, C. (2000). Kognitiver Fäbigkeitstest für 4. bis 12. Klassen, Revision (KFT $412+\mathrm{R}$ ) [Cognitive ability test for class level 4 to 12 , revised version]. Göttingen: Hogrefe.

Hoekman, K., McCormick, J., \& Barnett, K. (2005). The important role of optimism in a motivational investigation of the education of gifted adolescents. Gifted Child Quarterly, 49, 99110.

Hoekman, K., McCormick, J., \& Gross, M. U. M. (1999). The optimal context for gifted students: A preliminary exploration of motivational and affective considerations. Gifted Child Quarterly, 43, 170193.

Hoge, R. D., \& Renzulli, J. S. (1993). Exploring the link between giftedness and self concept. Review of Educational Research, 63, 449465.

Huguet, P., Dumas, F., Monteil, J. M., \& Genestoux, N. (2001). Social comparison choices in the classroom: Further evidence for students' upward comparison tendency and its beneficial impact on performance. European Journal of Social Psychology, 31, 557578.

Kanevsky, L., \& Keighly, T. (2003). To produce or not to produce? Understanding boredom and the honor in underachievement. Roeper Review, 26, 2028.

Kleinginna, P. R., \& Kleinginna, A. M. (1981). A categorized list of emotion definitions, with suggestions for a consensual definition. Motivation and Emotion, 5, 345379.

Köller, O. (2004). Konsequenzen von Leistungsgruppierungen [Effects of ability grouping]. Münster: Waxmann.

Larson, R. W., \& Richards, M. H. (1991). Boredom in the middle school years: Blaming schools versus blaming students. American Journal of Education, 99, 418443.

Lüdtke, O., Köller, O., Artelt, C., Stanat, P., \& Baumert, J. (2002). Eine Überprüfung von Modellen zur Genese akademischer Selbstkonzepte: Ergebnisse aus der PISA Studie. [Testing models on the genesis of academic self concepts: Findings of the PISA studyl. Zeitschrift für Pädagogische Psychologie, 16, 151164.

Marsh, H. W. (1987). The big fish little pond effect on academic self concept. Journal of Educational Psychology, 79, 280295.

Marsh, H. W. (1990). SelfDescription Questionnaire II. San Antonio, TX: Psychological Corporation. 
Marsh, H. W. (1991). The failure of high ability high schools to deliver academic benefits: The importance of academic self concept and educational aspirations. American Educational Research Journal, 28, 445480.

Marsh, H. W. (1994). Using the National Longitudinal study of 1988 to evaluate theoretical models of self concept: The Self Description Questionnaire. Journal of Educational Psychology, 86, 439456.

Marsh, H. W. (2005). Big fish little pond effect on academic self concept. German Journal of Educational Psychology, 19, 119127.

Marsh, H. W. (2007). Self concept theory, measurement and research into practice. The role of self concept in educational psychology. Leicester: British Psychological Society.

Marsh, H. W., Chessor, D., Craven, R., \& Roche, L. (1995). The effect of gifted and talented programs on academic self concept: The big fish strikes again. American Educational Research Journal, 32, 285319.

Marsh, H. W., \& Craven, R. (2002). The pivotal role of frames of reference in academic self concept formation: The big fish little pond effect. In F. Pajares \& T. Urdan (Eds.), Adolescence and education (Vol. 2, pp. 83 123). Greenwich, CT: Information Age.

Marsh, H. W., \& Hau, K. T. (2003). Big fish little pond effect on academic self concept: A cross cultural (26 country) test of the negative effects of academically selective schools. American Psychologist, 58, 364376.

Marsh, H. W., Hau, K. T., \& Craven, R. (2004). The big fish little pond effect stands up to scrutiny. American Psychologist, 59, 269271.

Marsh, H. W., \& Parker, J. W. (1984). Determinants of self concept: Is it better to be a relatively large fish in a small pond even if you don't learn to swim as well? Journal of Personality and Social Psychology, 47, 213231.

Marsh, H. W., Seaton, M., Trautwein, U., Lüdtke, O., Hau, K. T., O'Mara, A. J., \& Craven, R. G. (2008). The big fish little pond effect stands up to critical scrutiny: Implications for theory, methodology, and future research. Educational Psychology Review, 20, 319350.

Marsh, H. W., Trautwein, U., Lüdtke, O., Baumert, J., \& Köller, O. (2007). The big fish little pond effect: Persistent negative effects of selective high schools on self concept after graduation. American Educational Research Journal, 44, 631669.

Marsh, H. W., Trautwein, U., Lüdtke, O., Köller, O., \& Baumert, J. (2005). Academic self concept, interest, grades, and standardized test scores: Reciprocal effects models of causal ordering. Child Development, 76, 397416.

McCoach, D. B., \& Siegle, D. (2003). The structure and function of academic self concept in gifted and general education students. Roeper Review, 25, 6165.

Mikulas, W. L., \& Vodanovich, S. J. (1993). The essence of boredom. Psychological Record, 43, 312.

Neihart, M. (2007). The socioaffective impact of acceleration and ability grouping: Recommendations for best practice. Gifted Child Quarterly, 51, 330341.

Newberry, A. L., \& Duncan, R. D. (2001). Roles of boredom and life goals in juvenile delinquency. Journal of Applied Social Psychology, 31, 527541.

Pekrun, R. (2006). The control value theory of achievement emotions: Assumptions, corollaries, and implications for educational research and practice. Educational Psychology Review, 18, 315341 .

Pekrun, R., Goetz, T., \& Frenzel, A. C. (2005). Achievement Emotions Questionnaire Mathematics (AEQM) user's manual. Munich: Department of Psychology, University of Munich.

Pekrun, R., Goetz, T., Titz, W., \& Perry, R. P. (2002). Academic emotions in students' self regulated learning and achievement: A program of qualitative and quantitative research. Educational Psychologist, 37, 91105.

Plucker, J. A., \& McIntire, J. (1996). Academic survivability in high potential, middle school students. Gifted Child Quarterly, 40, 714. 
Plucker, J. A., Robinson, N. M., Greenspon, T. S., Feldhusen, J. F, McCoach, D. B., \& Subotnik, R. F. (2004). It's not how the pond makes you feel, but rather how high you can jump. American Psychologist, 59, 268269.

Preckel, F., \& Brüll, M. (2008). Grouping the gifted and talented: Are gifted girls most likely to suffer the consequences? Journal for the Education of the Gifted, 32, 5485.

Preckel, F, Zeidner, M., Goetz, T., \& Schleyer, E. (2008). Female 'big fish' swimming against the tide: The 'big fish little pond effect' and gender ratio in special gifted classes. Contemporary Educational Psychology, 33, 7896.

Pyryt, M. C., \& Mendaglio, S. (1994). The multidimensional self concept: A comparison of gifted and average ability adolescents. Journal for the Education of the Gifted, 17, 299305.

Robinson, W. P. (1975). Boredom at school. British Journal of Educational Psychology, 45, 141152.

Rogers, K. B. (1993). Grouping the gifted and talented: Questions and answers. Roeper Review, $16,812$.

Rogers, K. B. (2002). Effects of acceleration on gifted learners. In M. Neihart, S. M. Reis, N. M. Robinson, \& S. M. Moon (Eds.), The social and emotional development of gifted children: What do we know? (pp. 3 12). Waco, TX: Prufrock Press.

Rogers, K. B. (2007). Lessons learned about educating the gifted and talented: A synthesis of the research on educational practice. Gifted Child Quarterly, 51, 382396.

Scherer, K. R. (2000). Emotions as episodes of subsystems synchronization driven by nonlinear appraisal processes. In M. D. Lewis \& I. Granic (Eds.), Emotion, development, and self organization (pp. 70 99). Cambridge: Cambridge University Press.

Shields, C. M. (2002). A comparison study of student attitudes and perceptions in homogeneous and heterogeneous classrooms. Roeper Review, 24, 115119.

Sommer, B. (1985). What's different about truants? A comparison of eighth graders. Journal of Youth and Adolescence, 14, 411422.

Thackray, R. I. (1981). The stress of boredom and monotony: A consideration of the evidence. Psychosomatic Medicine, 43, 165176.

Thorndike, R. L., \& Hagen, E. (1971). Cognitive abilities test. Boston: Houghton Mifflin

Tidwell, R. (1988). Dropouts speak out: Qualitative data on early school departures. Adolescence, 23, 939954 .

Trautwein, U., Lüdtke, O., Marsh, H. W., Köller, O., \& Baumert, J. (2006). Tracking, grading, and student motivation: Using group composition and status to predict self concept and interest in ninth grade mathematics. Journal of Educational Psychology, 98, 788806.

Trautwein, U., Lüdtke, O., Marsh, H. W., \& Nagy, G. (2008). Within school comparisons: Perceived class prestige predicts academic self concept. Berlin: Max Planck Institute for Human Development.

Valentine, J. C., DuBois, D. L., \& Cooper, H. (2004). The relation between self beliefs and academic achievement: A systematic review. Educational Psychologist, 39, 111133.

Wagner, J. W. L. (1999). Soziale Vergleiche und Selbsteinschätzungen [Social comparisons and self estimates]. Münster: Waxmann.

Wagner, J. W. L. (2001). Leistungsvergleiche in der Schule. Bezugsgruppeneffekte und Fäbigkeitskonzepte [Comparisons of achievement in school. Reference group effects and academic self concepts] (Psychologie, Bd. 39). Landau: Verlag Empirische Pädagogik.

Wasson, A. S. (1981). Susceptibility to boredom and deviant behavior at school. Psychological Reports, 48, 901902.

Wiesner, M., Windle, M., \& Freeman, A. (2005). Work stress, substance use, and depression among young adult workers: An examination of main and moderator effects. Journal of Occupational Health Psychology, 10, 8396.

Zeidner, M., \& Schleyer, E. J. (1998). The big fish little pond effect for academic self concept, test anxiety, and school grades in gifted children. Contemporary Educational Psychology, 24, 305329. 